\title{
A Comparison of Different Finite Element Methods in the Thermal Analysis of Friction Stir Welding (FSW)
}

\author{
Bahman Meyghani ${ }^{1}$, Mokhtar B. Awang ${ }^{1, *}$, Seyed Sattar Emamian ${ }^{1}$, \\ Mohd Khalid B. Mohd Nor ${ }^{2}$ and Srinivasa Rao Pedapati ${ }^{1}$ \\ 1 Department of Mechanical Engineering, Universiti Teknologi PETRONAS, 32610 Bandar Seri Iskandar, \\ Perak Darul Ridzuan, Malaysia; Bahman.malaki.2009@gmail.com (B.M.); \\ Sattar.emamian@gmail.com (S.S.E.); Srinivasa.pedapati@utp.edu.my (S.R.P.) \\ 2 Fiction and Forge Processes Group, Joining Technologies Group, The Welding Institute (TWI) Ltd., \\ Cambridge CB21 6AL, UK; Khalid.Nor@twi.co.uk \\ * Correspondence: mokhtar_awang@utp.edu.my; Tel.: +605-368-7204
}

Received: 28 August 2017; Accepted: 22 September 2017; Published: 21 October 2017

\begin{abstract}
Friction Stir Welding (FSW) is a novel kind of welding for joining metals that are impossible or difficult to weld by conventional methods. Three-dimensional nature of FSW makes the experimental investigation more complex. Moreover, experimental observations are often costly and time consuming, and usually there is an inaccuracy in measuring the data during experimental tests. Thus, Finite Element Methods (FEMs) has been employed to overcome the complexity, to increase the accuracy and also to reduce costs. It should be noted that, due to the presence of large deformations of the material during FSW, strong distortions of mesh might be happened in the numerical simulation. Therefore, one of the most significant considerations during the process simulation is the selection of the best numerical approach. It must be mentioned that; the numerical approach selection determines the relationship between the finite grid (mesh) and deforming continuum of computing zones. Also, numerical approach determines the ability of the model to overcome large distortions of mesh and provides an accurate resolution of boundaries and interfaces. There are different descriptions for the algorithms of continuum mechanics include Lagrangian and Eulerian. Moreover, by combining the above-mentioned methods, an Arbitrary Lagrangian-Eulerian (ALE) approach is proposed. In this paper, a comparison between different numerical approaches for thermal analysis of FSW at both local and global scales is reviewed and the applications of each method in the FSW process is discussed in detail. Observations showed that, Lagrangian method is usually used for modelling thermal behavior in the whole structure area, while Eulerian approach is seldom employed for modelling of the thermal behavior, and it is usually employed for modelling the material flow. Additionally, for modelling of the heat affected zone, ALE approach is found to be as an appropriate approach. Finally, several significant challenges and subjects remain to be addressed about FSW thermal analysis and opportunities for the future work are proposed.
\end{abstract}

Keywords: Friction Stir Welding (FSW); Finite Element Methods (FEMs); Lagrangian; Eulerian; Arbitrary Lagrangian-Eulerian (ALE); Thermal Analysis

\section{Introduction}

For many years welding has been used as a very common method for joining materials. During the historical investigations, for the first time the welding was used by the Sumerian civilization in order to weld copper utensils. After the 20th century the significance of the welding was increased sharply, because after the First World War, in the Treaty of Versailles, building ships heavier than 10,000 tons was prohibited for all countries. Then, the study on the use of the advanced joining methods for warships was began by German engineers [1] and after a while they could reduce 1000's of tons of the ship 
weight. Therefore, without violating the treaty, Germany could build large warships while their weight was still less than 10,000 tons. Later, the weight was becoming as a significant factor in designing and building ships, though the motivation for Germany was ill suited; the thought process was leading the industry of manufacturing to a new heightened level of thinking. According to the necessity of reducing fuel consumption, the need for designing and manufacturing lightweight constructions like vehicle body shells, aircraft and offshores panels is also increased [2-6]. Therefore, the significance of advanced joining methods is highlighted more than before. Thus, a lot of researchers [7-11] have been focused on developing new joining methods and assess their capabilities for manufacturing lightweight structures.

Friction Stir Welding (FSW), is a solid-state welding process which was invented in 1991 by The Welding Institute (TWI), UK [12]. Although FSW is often employed as a technique for welding aluminum alloys $[13,14]$, but it has also been used for welding of many other metals such as magnesium alloys [15,16], titanium alloys [17,18] and metal-matrix composites [19,20]. Moreover, similar or dissimilar materials in different thickness can be welded by this method. It should be noted that, in this welding method, there is no need to use expensive consumables such as cover gases. Additionally, the process can be automated and mechanized, the work-piece distortion is low and the mechanical properties is good [21,22]. Besides, through this method the energy consumption, the impact on the environment, and the costs are decreased.

During the process, a tool which consist of a shoulder and a pin, rotates and plunges inside the material, then it transfers along the welding seam. Therefore, the welded material during process moves from the front side to the back side of the tool and after, string and softening of the material, the material moves from the front side (leading edge) to the back side (trailing edge) of the tool [23,24]. To develop welding conditions, the welding parameters at different welding stages (as illustrated in Figure 1) should be investigated in studying the process thermal behavior more in detail, the modelling techniques could be as a cost-efficient approach. It need to be mentioned that, the heat generation in FSW has two main sources, the friction force and the plastic deformation. Figure 1 shows the principle of the FSW process [25-27].

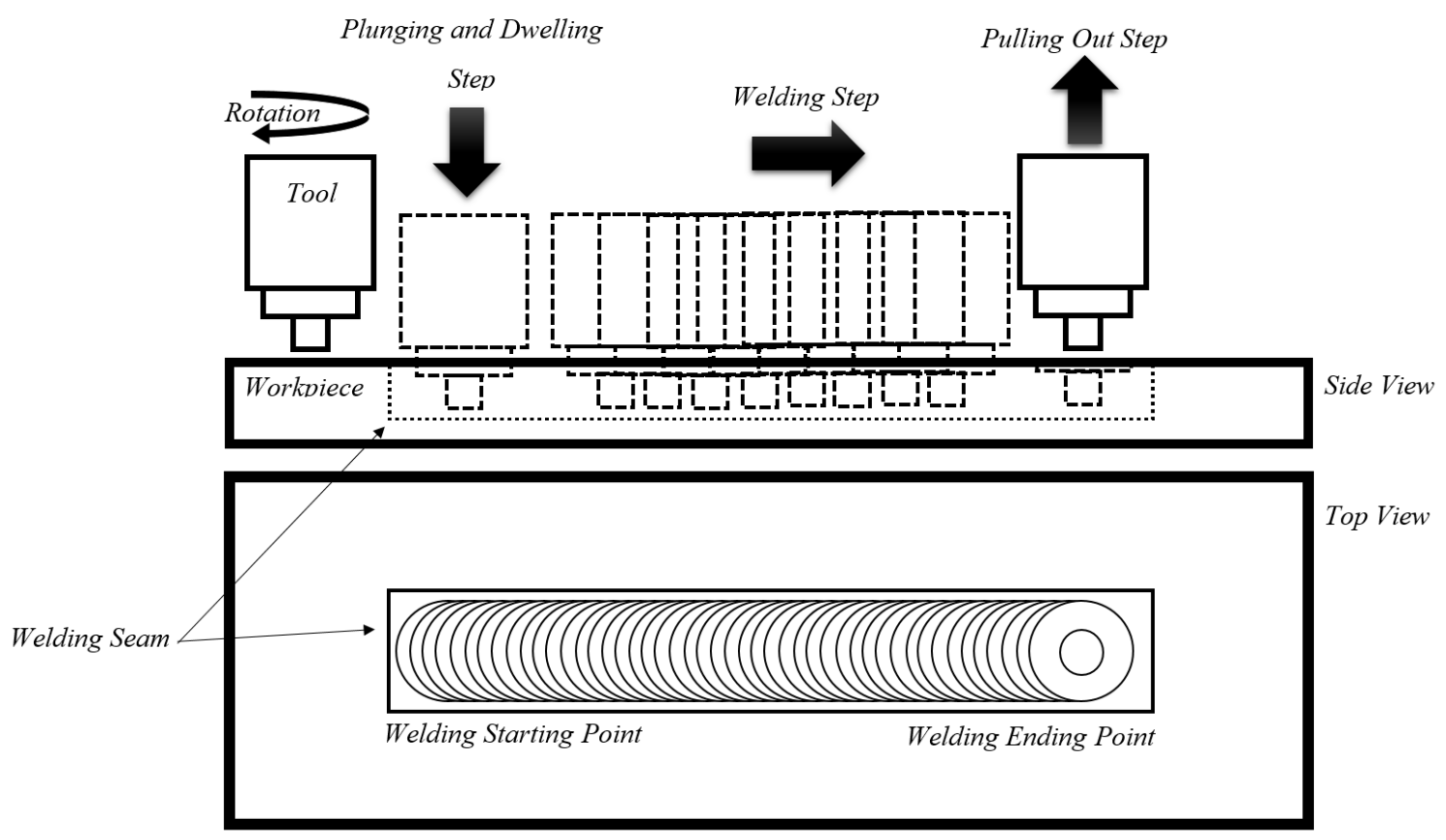

Figure 1. The principle of the FSW process. 


\section{Thermal Analysis of FSW (Friction Stir Welding)}

As mentioned earlier, in comparison to non-linear (highly coupled) physical phenomena, FSW is a very complicated process due to the presence of severe plastic deformation (SPD), complicated material flow behavior, friction between interfaces, mechanical stirring, dynamic structural evolution and the generation of the heat. According to the literature although [28-31] the welding temperature is always lower than the base material melting point, however during the process, the welding temperature is high enough to change the material phase. Therefore, due to the influence of the heat in producing acceptable welding quality, the study of the welding thermal history is significant [32-34]. Through only experiments, investigating the process in depth and predicting the thermal behavior of the weld is not attainable [35], because temperature measurements during experiments is done frequently by using thermocouples $[36,37]$ and the measurement of the temperature inside the welding nugget zone by using thermocouples is challenging. Thus, as mentioned earlier, the Finite Element Methods (FEMs) are proposed as an efficient and suitable method to study the thermal behavior [38]. Basically, Finite Element is a dominant discretization method in structural mechanics in which a complex model is separated (subdivided) into disjoints components of small geometries. Moreover, Finite Element Methods can capture much of the complexity of the process, and whereby the differential equations governing the process can be determined by using these methods [39,40]. Therefore, FEMs attract enormous research interests over the past two decades.

Mishra and Ma [41] reviewed comprehensively Friction Stir Processes (FSP) and FSW. The results indicated that, the flow of the material has a complicated pattern, therefore the investigation of the material deformation during the process is challenging. It is also noted that, there are several factors which affect the flow of the material that include the tool geometry (shoulder and pin), the welding rotational and transverse velocities, the depth of the plunge, the tool tilt angle, the material being welded and the initial temperature.

A comparison study is done by Threadgill et al. [42] for the FSW of aluminum alloys and Çam [43] studied widely other alloys. Developments of microstructures and the properties of material during the FSW was done by He et al. [44]. The results from the research indicated that, the material properties, the tool geometry and the joint shape affect the welding quality.

As cited in the above paragraphs, so far, no investigators or researchers have reviewed the different continuum mechanics algorithms for modelling the process. The review of the numerical continuum mechanics algorithms can be used as a guide for choosing the best algorithm, which can support to identifying the novelty of the proposed approach in this paper.

Moreover, some researchers [45-47] were focused on the thermography method which has been defined as a modern method for investigating the thermal field through online monitoring of the process, inspection and research. It should be mentioned that, this method is mainly used to determine the thermal field variations, when the measurements are difficult or impossible to record (i.e., inside the weld). Furthermore, the accuracy of the measurements in this method can be increased if proper calibration of the data is realized.

In conclusion, the results from the reviewed literature indicated that, in comparison to the destructive tests the costs and the time in the thermography method are lower. However, in comparison to the numerical methods thermography method are more expensive. In addition, in the thermography method there is no need to validate and verify the model by experimental measurements.

\section{Initial Selection for Finite Element Modelling of the FSW Process}

In order to simulate the process more accurately some of the initial selection need to be investigated by the researchers such as the size of the mesh, the material input parameters and the selection of the finite element package, because all of the mentioned factors will affect the accuracy of the simulated model and the computation cost. 


\subsection{Mesh Size and Mesh Type}

As claimed by researchers the size of the mesh would highly affect the accuracy of the simulated model [48]. For example, the element size of $0.3 \mathrm{~mm}$ was used in order to numerical and experimental simulation of the FSW process in which a high modelling accuracy was achieved [49]. Moreover, the average mesh size of $0.1 \mathrm{~mm}$ near the stir zone was selected by Kim et al. [50]. It needs to be mentioned that the authors compared the results with experiments and good agreement was achieved. In order to save the time, the element size of $4 \mathrm{~mm}$ was used far from the welding seam, while near to the heat affected zone the size of $0.8 \mathrm{~mm}$ was employed [51]. In one study [52], the size of the mesh varied in a range of $2.5 \mathrm{~mm}$ to $20 \mathrm{~mm}$ in order to investigate the temperature distribution. Experimental measurements during the welding showed that the accuracy of the model was acceptable when compared to the criteria defined in the research.

From the above-mentioned literature, it was summarized that, number of nodes are highly dependent on the shape of the element and the order of interpolation. Moreover, the selection of the element usually needs the expert knowledge of theory and the knowledge of applying finite element analysis (FEA). For various problems and analyses, some guidelines for the selection of the element are proposed. It should be noted that the user needs to know about:

- Applying different degrees of freedom for each node that are depending on the analysis solution field such as rotation, displacement, temperature and the order of modeling space like 1D, 2D and 3D.

- Numerical simulation formulation is different for different element families.

- Integration including reduced and full integration.

- All of the loads such as body forces, gravity or surface pressure can be applied on both the solid and the shell elements, however line forces distributions can be only applied on the beam and the shell elements.

- All kinds of elements are appropriate geometrically in order to non-linear analysis (except the small-strain shell element). Generally, there is no restriction on the material type that would be employed for each element. Majority of the elements are able to be employed in both explicit and standard solvers.

\subsection{Finite Element Software Packages}

Another significant point in the numerical simulation of the FSW process is the selection of the finite element software package. There are some points that need to be considered during the modelling of FSW. Three different software commonly used for modelling the FSW process including ABAQUS $^{\circledR}$, ANSYS $^{\circledR}$ and FLUENT ${ }^{\circledR}$ [53]. Table 1 summarizes the software packages used to simulate the FSW process.

In conclusion, FEMs allow detailed visualization of structures during bending or twisting. These methods also indicate the distribution of stresses and displacements. In the above section, a brief summery has been presented on different commercially available finite element software packages detailing their applicability for performing FSW process including thermomechanical behavior, fatigue behavior, plastic deformation, stress and friction modelling.

To sum up the results showed that, the software of ABAQUS ${ }^{\circledR}$ and ANSYS ${ }^{\circledR}$ are the prominent software in terms of simulating mechanical properties, deformations, heat transfers and temperature distributions. It was also observed that in the material flow and the fluid dynamic modelling, FLUENT ${ }^{\circledR}$ shows more accurate achievements. 
Table 1. Different software packages capabilities.

\begin{tabular}{|c|c|c|c|}
\hline Capability & ABAQUS & FLUENT & ANSYS \\
\hline Geometry modeling & $\begin{array}{l}\text { The program features very general geometry } \\
\text { modelling capabilities (two- and } \\
\text { three-dimensional continua, beams, } \\
\text { membranes, shells, trusses, cables, gaps, etc.). }\end{array}$ & $\begin{array}{l}\text { - Extract volumes/create inner fluid domains and } \\
\text { outer air enclosures for computer fluid } \\
\text { dynamic (CFD). } \\
\text { - Create shared topology among bodies to } \\
\text { generate conformal meshes. }\end{array}$ & $\begin{array}{l}\text { - Geometry modelling in the ANSYS Workbench } \\
\text { environment is highly automated. } \\
\text { Provides users the flexibility to customize } \\
\text { according to the type of analysis or application. }\end{array}$ \\
\hline Material modeling & $\begin{array}{l}\text { A large library of materials (isotropic and } \\
\text { anisotropic elasticity, visco-elasticity, } \\
\text { hyper-elasticity, hypo-elasticity, foam } \\
\text { elasticity, plasticity, metal plasticity, } \\
\text { visco-plasticity. }\end{array}$ & $\begin{array}{l}\text { Materials can be downloaded from the global database } \\
\text { or defined locally. } \\
\text { An integrated library of both fluid and solid material } \\
\text { properties that allows you to rapidly search for and } \\
\text { specify material data. }\end{array}$ & $\begin{array}{ll}\text { - } & \text { Linear Material Models. } \\
\text { - } & \text { Rate Dependent Plasticity. } \\
\text { - } & \text { Rate Dependent Hyper elasticity. } \\
\text { - } & \text { Viscoelasticity. } \\
\text { - } & \text { Creep. } \\
\text { - } & \text { Reactive Materials. }\end{array}$ \\
\hline $\begin{array}{l}\text { Adaptive meshing } \\
\text { capability }\end{array}$ & $\begin{array}{l}\text { Partial support, and fine control in adaptive } \\
\text { meshing. }\end{array}$ & $\begin{array}{l}\text { Multiphase (Dispersed phase model (DPM), Eulerian } \\
\text { and Volume of fluid model (VOF)), combustion \& } \\
\text { chemical reaction, dynamic meshing. }\end{array}$ & $\begin{array}{l}\text { - } \quad \text { Automatic surface meshing } \\
\text { - } \quad \text { Automatic tetrahedral meshing } \\
\text { - } \quad \text { Automatic hexa-core meshing } \\
\text { - } \quad \text { Automatic swept hex meshing } \\
\text { - } \quad \text { Thin-sweep meshing. }\end{array}$ \\
\hline Temperature profile & $\begin{array}{l}\text { Having broad range for modeling transient } \\
\text { and steady-state heat transfer, fully coupled } \\
\text { temperature/stress. }\end{array}$ & $\begin{array}{ll}\text { - } & \text { Conduction } \\
\text { - } & \text { Convection } \\
\text { - } & \text { Padiation } \\
\text { Phase change. }\end{array}$ & $\begin{array}{ll}\text { - } & \text { Steady State } \\
\text { - } & \text { Transient } \\
\text { - } & \text { Conduction } \\
\text { - } & \text { Convection } \\
\text { - } & \text { Radiation } \\
\text { - } & \text { Phase Change. }\end{array}$ \\
\hline
\end{tabular}


Table 1. Cont.

\begin{tabular}{|c|c|c|c|}
\hline Capability & ABAQUS & FLUENT & ANSYS \\
\hline $\begin{array}{l}\text { Stresses and } \\
\text { Residual stress }\end{array}$ & $\begin{array}{l}\text { A broad range of procedures (static and } \\
\text { dynamic stress). }\end{array}$ & $\begin{array}{l}\text { Geometry is usually suitable for simulating flows of } \\
\text { the material and is not suitable for solid parts. } \\
\text { Limitations in element kinds. }\end{array}$ & $\begin{array}{l}\text { Includes static stress analysis including nonlinear } \\
\text { contact, structural joints and large deflections to } \\
\text { accurately compute static deflections and stresses for } \\
\text { complex parts and assemblies. } \\
\text { Includes modal analysis to determine the natural } \\
\text { frequencies and vibration characteristics of your } \\
\text { product designs, and both stress-life and strain-life } \\
\text { fatigue analysis. }\end{array}$ \\
\hline Flow of material & Fully coupled pore fluid flow/stress. & $\begin{array}{ll}\text { - } & \text { Steady-State Flow. } \\
\text { - } & \text { Transient Flow. } \\
\text { - } & \text { 2-D and 3-D Flow. } \\
\text { - } & \text { Periodic domains. } \\
\text { Dynamic/moving-deforming mesh. }\end{array}$ & $\begin{array}{l}\text { In contrast with FLUENT the flow of the material is } \\
\text { not available in the ANSYS package. }\end{array}$ \\
\hline Deformations & $\begin{array}{l}\text { ABAQUS includes several advanced } \\
\text { techniques for modelling extreme } \\
\text { deformation and fluid flow. }\end{array}$ & $\begin{array}{l}\text { Flow deformation in the software is available } \\
\text { including the velocity of the flow and etc. }\end{array}$ & $\begin{array}{ll}\text { - } & \text { Large strain. } \\
\text { - } & \text { Large deflection. } \\
\text { - } & \text { Stress stiffening. }\end{array}$ \\
\hline Overall control & $\begin{array}{l}\text { Very high control, basic solver functioning } \\
\text { can be modified. }\end{array}$ & $\begin{array}{l}\text { FLUENT (ANSYS }{ }^{\circledR} \text { ) is better for simple simulations } \\
\text { having } 0-2 \text { moving ref frames. Beyond that, it gets } \\
\text { scarily complicated. } \\
\text { Also, other parameters such as the type of meshing, } \\
\text { accuracy required, flow parameters and etc. always } \\
\text { affect your choice of solver. }\end{array}$ & $\begin{array}{l}\text { - } \quad \text { Faster meshing. } \\
\text { - } \quad \text { Gasier contact treatment. } \\
\text { - Works best when the number of bodies to be } \\
\text { analyzed is high. }\end{array}$ \\
\hline
\end{tabular}




\subsection{Material Data}

The material data is directly affect the accuracy of the simulated model, because during the FSW process temperature is varied from the room temperature to the material melting point [54]. Therefore, the material input parameters have a direct influence in the accuracy of the simulated model. Table 2 summarizes the recent developments who have used constant or temperature dependent material input parameters.

Table 2. A summary of recent progress which are employed constant or temperature dependent material data.

\begin{tabular}{ll}
\hline \multicolumn{1}{c}{ Authors and Objectives Material Data } & \multicolumn{1}{c}{ Results } \\
\hline $\begin{array}{l}\text { Peel, Mishra, Mishra and Ma, Nandan et al. [40,55-58]. } \\
\begin{array}{l}\text { To investigate technical properties and residual stresses as a function } \\
\text { of welding speed. } \\
\text { Young's modulus of 73 GPa and the Poisson's ratio of 0.3 were used. }\end{array}\end{array}$ & $\begin{array}{l}\text { The results showed that the use of the constant } \\
\text { material property will affect the accuracy of the } \\
\text { model in the temperature field. }\end{array}$ \\
\hline $\begin{array}{l}\text { Veljić et al. [59]. } \\
\begin{array}{l}\text { To investigate the heat generation during plunge stage in FSW } \\
\text { (Friction stir welding). }\end{array}\end{array}$ & $\begin{array}{l}\text { The influence of the friction-generated heat is more } \\
\text { than the plastic deformation. } \\
\text { The slip rate of the tool and the temperature relative } \\
\text { to the workpiece is related heat generated by friction. }\end{array}$ \\
\hline $\begin{array}{l}\text { Secondly, the material velocity is related to the heat } \\
\text { generated by the plastic deformation. }\end{array}$ \\
$\begin{array}{l}\text { Sun et al. [60]. } \\
\text { To predict the peak temperatures and the residual stresses. }\end{array}$ & $\begin{array}{l}\text { In comparison with the conventional FSW, the } \\
\text { material flow being affected by the rotating probe, the } \\
\text { (stationary shoulder FSW; SSFSW) process produced } \\
\text { narrower and more uniform weld nugget and heat } \\
\text { affected zone. }\end{array}$ \\
\hline
\end{tabular}

Garg and Bhattacharya [61].

To investigate the influence of the different tool pin shapes along with the tool rotational speed and the dwell time on the lap shear strength of FSW.

Constant Poison's ratio of 0.3 and Young's modulus ( $E=68.9 \mathrm{GPa})$.

Bussetta et al. [62].

To model Thermomechanical behaviour of FSW.

Constant Young's modulus of 70.4 GPa and Poisson's ratio of 0.33 .

Jain et al. [63].

To investigate temperature and strain distribution.

Young's modulus and poison ratio of $68.9 \mathrm{GPa}$ and 0.33 .

The shear strength was significantly influenced by the tool rotational speed followed by the pin shape and the dwell time.

Riahi and Nazari, Aziz, Maisonnette, Al-Badour et al. [64-67].

To analyse the transient temperature and residual thermal stresses.

Temperature dependent values of the Young's modulus.

Riahi and Nazari [64].

To analyse the transient temperature and residual thermal stresses. Young's modulus from $68.9 \mathrm{GPa}$ in $25^{\circ} \mathrm{C}$ to $31.72 \mathrm{GPa}$ in $426.7^{\circ} \mathrm{C}$ and a constant Poisson's ratio of 0.33 .

Al-Badour et al. [67].

To investigate FEM of FSW.

Young's modulus from $66.94 \mathrm{GPa}$ to $20.2 \mathrm{GPa}$ at the variation of the temperature in a range of $25{ }^{\circ} \mathrm{C}$ to $482{ }^{\circ} \mathrm{C}$ was considered.

Maisonnette et al. [66].

To find the mechanical behaviour at high temperature during FSW.

Temperature dependent Young's modulus.
Fluid and a solid different formula lead to the same results.

The temperature distribution on the workpiece and the tool was predicted.

The maximum temperature was observed higher at the top surface of the workpiece.

Assumptions and simplifications are often proposed for the simulation of the FSW and a good agreement was achieved.

Heat is generated due to the friction between the tool and the workpiece. Thermal behaviour of the workpiece was considered as an inlet heat of an elasto-plastic, thermomechanical model for predicting of the residual stress. Moreover, the heat distribution along the thickness varied and was found asymmetrical.

Because of the consideration of the adiabatic heating effect, the maximum estimated temperature remains equal to the material solidus temperature $\left(583^{\circ} \mathrm{C}\right)$ and it was set in the Johnson-Cook material model.

The temperature was continuously varying, first increasing (during heating) and then decreasing (during cooling) without dwell-time at the highest temperature.

Among all of the welding parameters, the effect of the rotational speed on heat generation was found higher than the transverse speed. 
In conclusion, it must be mentioned that, the constant material data in the literature was often restricted to lower temperatures and lower plastic deformations. It is anticipated that during the FSW process a high range of temperature variations and large plastic deformation are available. Therefore, the accuracy of those models in which temperature dependent material data were employed was observed higher. Furthermore, it was obtained that the elastic modulus is one of the most significant input parameters, because an accurate definition of it can solve the mesh distribution problem. It should be noted that other temperature dependent parameters like thermal conductivity, thermal expansion, specific heat, density, yield and tensile strengths need to be considered accurately.

\section{Different Welding Zones and Different Modelling Scales}

As can be seen in Figure 2, the workpiece is separated into different welding zones [68-72]. Parent material, Heat Affected Zone (HAZ) in which, a nonlinear temperature heat conductivity is available, Thermo-Mechanically Affected Zone (TMAZ) in which, extremely large plastic deformation, nonlinear heat conductivity and asymmetric temperature profile are present. Moreover, there is a small area named stirring zone which is located inside the TMAZ zone. Therefore, different boundary conditions and different contact models have to be considered for each zone in order to precisely predict the thermal behavior during the welding process.

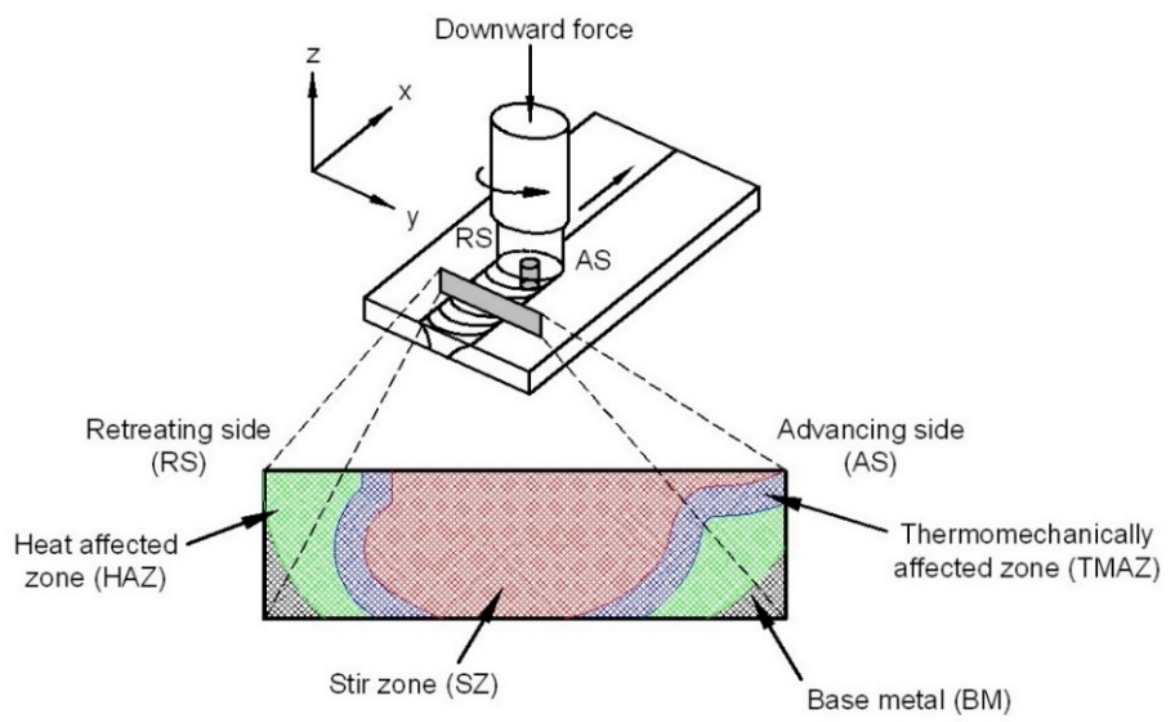

Figure 2. Different welding zones.

Basically, the modelling of the process is divided into two scales. Investigating the effect of the welding parameters (i.e., welding transverse and rotational speeds), the contact mechanisms (i.e., the friction coefficient), the contact model selection and the thermal behavior in the heat affected zone is named local level. Whilst global level analysis is used to study the influence of the distortions of the residual stresses and the temperature in the entire structure.

Three different numerical methods have been suggested by researchers to investigate the behavior of the process at local and global scales, Lagrangian, Eulerian and Arbitrary Lagrangian-Eulerian (ALE) [54,73]. The differences between these approaches are shown in Figure 3. 


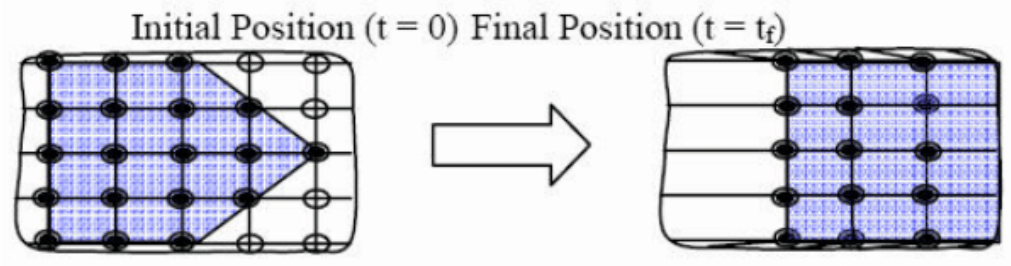

LAGRANGIAN MESH

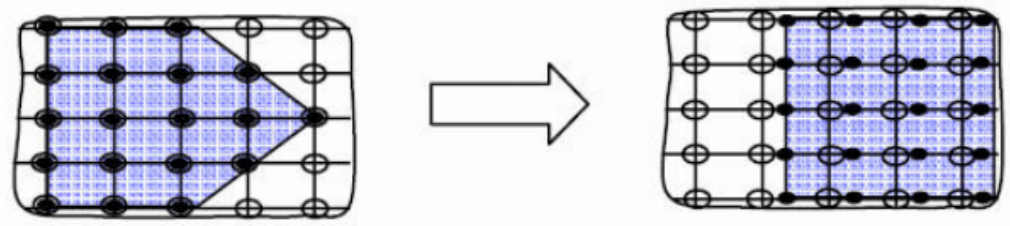

EULERIAN MESH

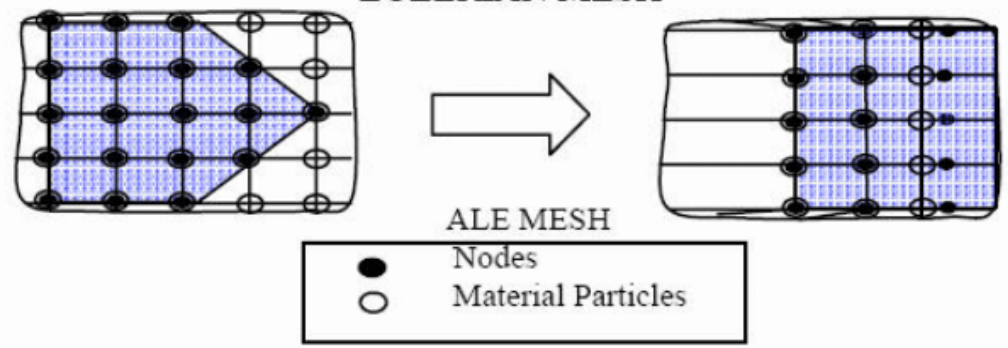

Figure 3. The difference in the Lagrangian, Eulerian and Arbitrary Lagrangian-Eulerian (ALE) methods.

All different numerical modelling approaches i.e., Finite Element, Finite Volume and Finite Difference can be divided into two main categories, namely Lagrangian and Eulerian. In both the domain is divided to nodes and elements. In the former nodes and elements are able to distort and move with the deformation of the material [74]. While, in the latter both of the nodes and elements are remaining constant and only the material can flow in the entire of the domain [75].

Both approaches provide benefits and challenges. The Lagrangian method only work well in those problems in which the distortion of mesh is not large such as static problems. In contrast, the Eulerian formulations handle flow of the materials quite easier. However, the user challenging is sufficiently refinement of the mesh size, or implementing a second accurate solution for decreasing the numerical dispersion.

There is a recently growing technique for modelling processes in which the Lagrangian and the Eulerian methods are combined into a single numerical approach called the Arbitrary Lagrangian Eulerian (ALE) [76]. In this approach, a user specifies a set of metrics that informs the analysis code in order to use the Lagrangian or the Eulerian. These metrics may include element volume, skew, temperature, or other similar properties. Coupling these two approaches (Lagrangian and Eulerian) seems to be the most viable option for modelling large plastic deformation problems.

\section{Global Scale}

\subsection{Lagrangian, Eulerian Methods}

Lagrangian method is mainly employed in combination with the solid and the structural elements. Researchers $[77,78]$ considered that, in the case of FSW the Lagrangian method can achieve accurate results at the global scale. As mentioned earlier in this method, the nodes move with the material and follow the material deformation. Therefore, in this method there is no material passes between elements, which make this method suitable for investigating the process wherever the distribution of mesh is not large (outside of the welding zone). 
Gould and Feng [79] suggested a simplified Lagrangian model for predicting the temperature profile and the heat transfer within the FSW process. The Lagrangian method with severe re-meshing was used in some models [80-82] in which thermal analysis and stress outcomes were successfully predicted.

Lagrangian formulation and implicit method were employed in Buffa et al. [82] study, using a coupled thermomechanical FEM in DEFORM-3D ${ }^{\circledR}$ commercial software. In the model, continuum elements were used for modelling of the welding seam. Moreover, a rigid visco-plastic material description was employed to study the influence of the welding parameters in temperature profile, strain rate, material flow and welding forces. Finally, good agreements were achieved in the term of welding forces and temperatures. It was determined that, the temperature profile across the welding line is approximately symmetrical and mostly influenced by angular velocity. While the material flow in the welding zone was observed as a non-symmetrical phenomenon which was mostly dominated by both welding transverse and angular velocities.

A Lagrangian thermal FE model was done for simulating friction welding by Mitelea and Radu [83]. In their research, the model was compared with other heat flux models to achieve a good correlation between the experimental observations and the numerical results. More accurate solution in terms of the heat flow reached due to the use of both numerical and analytical techniques. According to the research achievements, if the friction welding is assumed as a short duration process; the accuracy of the transient model in comparison with the steady state model would be higher.

For predicting the temperature during the welding of 1045 steel, a Lagrangian model was established by Nguyen and Weckman [83]. In the model, a transient thermal condition in which the power was recorded experimentally and defined in the model as a constant value was used.

Dong et al. [84] and Chao et al. [85] compared the experimental and the numerical results of the generated heat energy during FSW using the Lagrangian method. In Chao's model, a steady state condition was employed for the tool and a transient condition was used for the plates. Temperature evolution was recorded experimentally for validating the results. WELDSIM code was used to simulate the workpiece, however a symmetric condition was assumed between the advancing and the retreating sides, thus only half part of the workpiece was modelled. The results indicated that, around $95 \%$ of the generated heat during the welding goes into the sheets and $5 \%$ of it goes to the welding tool. In some Lagrangian FE models, over-prediction problem solved by experimentally measuring of the power data and defining this data as an input parameter in the model. These models [85-91] also were used to find the effect of the latent heat in the peak temperature.

Visco-plastic material behavior and temperature dependent material properties, in Lagrangian condition were used by Maol and Massoni [88]. In the model, experimental measurements of the velocity and pressure were recorded to determine the value of the friction force.

To study the temperature profile, a three dimensional model was used by Khandkar et al. [92]. In their research, experimental observations were used to measure the generated heat and the torque amount for butt welds. Moreover, temperature-dependent material properties were employed to achieve more accurate results. The results indicated that the most important source of the heat production is the force of the friction.

Hamilton et al. [93] and Khandkar et al. [92] employed a torque base heat input parameter to find the maximum welding temperature for $304 \mathrm{~L}$ stainless steel and various aluminum alloys. Energy-slip factor was established in a thermal model to find the relationship between the energy per unit length and the solidus temperature.

Moreover, different thermal models were used in a coupled condition to investigate the mechanical behavior and the residual stress [94]. In a three dimensional thermomechanical FE model, Dong et al. [95] used an axisymmetric Lagrangian method for investigating forces impact on the tool in different welding transverse and rotational speeds.

A three dimensional visco-plastic model was employed to investigate the deviatoric stress tensor [96]. In the research, parametric studies were done to explore the influence of the welding 
parameters (transverse and rotational speeds) on the pin forces and the plate temperatures. Observations indicated that the rise in the tool rotational movement increases the welding temperature. Conversely, the rise in the transverse movement of the tool reduces the welding temperature. Eventually, by comparing experimental observations of the temperature, the validation and verification of the simulated model was done.

By using the Lagrangian method and re-meshing technique in ANSYS ${ }^{\circledR}$ coupled thermo-mechanical modelling of Al 6061-T6 was established by Chen and Kovacevic [97]. In the model, the tool shoulder was simulated as a source for the heat. Moreover, the influence of the moving heat source in the workpiece temperature was studied. However, the influence of the pin was assumed as a neglected amount and the model was limited in the field of strain rate, stresses and forces.

As claimed by researchers [98-100], the Eulerian formulation was seldom used for thermal analysis of the process, because unlike the Lagrangian method, in the Eulerian formulation the mesh is fixed and the material can move between the boundaries. Therefore, the Eulerian setting was widely used in those processes in which the material travels through the grid such as fluid mechanics problems. Moreover, the application range in the Eulerian formulation is limited, because a proper definition of the convection term, the material properties, and the geometry of the parts in this formulation are required [101].

A steady state model was investigated by Bastier et al. [100]. There were two different stages in the simulation. In the first step, the Eulerian formulation and re-meshing technique were used in order to model the pin motion. In the latter, based on an elasto visco-plastic constitutive law a steady-state algorithm was used to estimate the residual stress.

The evaluation of the thermal contact conductance was done by Contuzzi et al. [102]. It was observed that the thermal contact conductance is a useful tool for investigating the fraction of heat during the process. Moreover, it was investigated that there is a "V" contour for the temperature across the welding cross section.

Bendzsak et al. [98,99] investigated the material flow by using the Eulerian formulation. Furthermore, the Eulerian formulation was used by Cho et al. [103] for the thermomechanical investigation of the process. However, in the model the transient temperature was not considered and also the effect of the temperature on the viscosity was neglected. Therefore, a large gap between the results of the numerical model and the experiments in the field of the temperature was reported. The results showed that, for welding of similar materials, the viscosity is independent of temperature and has a heuristic behavior. However, for dissimilar materials by using a transient thermal model, a complicated viscosity behavior was found.

A coupled Eulerian Lagrangian method is used to investigate the defect formation [104]. The results indicated that the void size was highly dependent on the welding rotational and transverse speeds. In addition, in comparison to the simple pin, the featured pin increases the material plastic deformation, resulting a defect-free weld (when optimized welding condition was used). A brief summary about the Lagrangian and the Eulerian methods are concluded in Table 3.

In conclusion, it was found that the Lagrangian method allows the smooth movement of the interfaces and surfaces into the materials. Moreover, by using this method the materials treatment with history-dependent constitutive relations is facilitated. However, the incapability of following large distortions of the computational domain without recourse for frequent remeshing operations, can be defined as a weakness (limitations) for this method. Furthermore, the Eulerian method has been widely employed for fluid dynamics problems, because in this method the computational mesh is fixed and the continuum is able to move through the grid. By using this method, the large distortions of the continuum motion are able to be handled with ease, and the resolution of the flow details and the precise definition of the interface can be defined as a drawback. 
Table 3. Summary and an outlook of the research which used the Lagrangian and Eulerian methods.

\begin{tabular}{|c|c|c|}
\hline Authors & Objectives & Results \\
\hline Fu and Ghanimi et al. $[77,78]$. & $\begin{array}{l}\text { To investigate } \\
\text { Thermomechanical behavior of inertia welding. }\end{array}$ & $\begin{array}{l}\text { Good agreement results for the temperature was achieved. Lagrangian was found as a } \\
\text { suitable method for modelling inertia friction welding. Moreover, the results indicated } \\
\text { that the model is able to be employed for predicting the evolutions of the temperature } \\
\text { profile, strain, stress, and geometry. }\end{array}$ \\
\hline Gould and Feng [79]. & To study of the heat transfer. & $\begin{array}{l}\text { The temperature predicted at the global scale. Temperature at the welding advancing } \\
\text { side was reported more than the welding retreating side. }\end{array}$ \\
\hline Buffa et al. [81]. & $\begin{array}{l}\text { To find the influence of the welding parameters in } \\
\text { welding forces, strain rate, temperature profile and } \\
\text { material flow. }\end{array}$ & $\begin{array}{l}\text { Good agreements achieved in the term of forces and temperatures, because of using the } \\
\text { Lagrangian method. Moreover, the temperature profile across the welding line was } \\
\text { found symmetrical and mostly influenced by the angular velocity. }\end{array}$ \\
\hline Chenot and Massoni, Buffa et al. [80-82]. & To develop a model for thermal simulation of FSW. & $\begin{array}{l}\text { Lagrangian was found as a suitable method for thermal analysis and stress analysis at } \\
\text { global level. }\end{array}$ \\
\hline Nguyen and Weckman [83]. & To find challenges of the process thermal analysis. & $\begin{array}{l}\text { Predicting temperature during the welding of } 1045 \text { steel. The temperature profile was } \\
\text { studied and good agreement was found. }\end{array}$ \\
\hline Mitelea and Radu [83]. & To compare different heat flux models. & $\begin{array}{l}\text { Lagrangian model was found to be a suitable method for thermal analysis of the FSW of } \\
\text { dissimilar material. }\end{array}$ \\
\hline Dong et al. [84] and Chao et al. [85]. & $\begin{array}{l}\text { To analyses thermomechanical behavior of } \\
\text { the process. }\end{array}$ & $\begin{array}{l}\text { Results indicated that, most of the generated heat (around } 95 \% \text { ) goes to the welding } \\
\text { sheets and only } 5 \% \text { of the heat goes into the welding tool. }\end{array}$ \\
\hline $\begin{array}{l}\text { Chao, Song and Kovacevic, Dialami, } \\
\text { Colegrove et al. [85-91]. }\end{array}$ & $\begin{array}{l}\text { To model the heat transfer and analyses thermal and } \\
\text { thermo-mechanical behavior. }\end{array}$ & $\begin{array}{l}\text { Lagrangian was found as a suitable method for finding the effect of the latent heat in the } \\
\text { peak temperature and also modelling the transient heat transfer. }\end{array}$ \\
\hline Maol and Massoni [88]. & To determine the friction force. & $\begin{array}{l}\text { By using Lagrangian approach the value of the friction force was determined. Friction } \\
\text { force was found one of the key sources for the generation of the heat in FSW. }\end{array}$ \\
\hline Khandkar et al. [92]. & $\begin{array}{l}\text { To investigate the temperature profile and } \\
\text { heat generation. }\end{array}$ & $\begin{array}{l}\text { The results indicated that the main source for the generation of the heat is the } \\
\text { frictional force. }\end{array}$ \\
\hline $\begin{array}{l}\text { Hamilton et al. [93]. } \\
\text { Khandkar et al. [92]. }\end{array}$ & To find the peak temperature. & $\begin{array}{l}\text { A thermal model was developed successfully. Thermal history was investigated and the } \\
\text { peak temperature was found higher in the advancing side. }\end{array}$ \\
\hline Khandkar [94]. & $\begin{array}{l}\text { To investigate the mechanical behavior and the } \\
\text { residual stress. }\end{array}$ & $\begin{array}{l}\text { Lagrangian was found as an appropriate method for finding the thermal analysis of } \\
\text { FSW, investigating mechanical behavior and also the residual stress. }\end{array}$ \\
\hline Dong et al. [95]. & To explore the influence of the forces in the tool. & $\begin{array}{l}\text { The effect of the welding rotation and transverse movements in the temperature was } \\
\text { successfully investigated. }\end{array}$ \\
\hline
\end{tabular}


Table 3. Cont.

\begin{tabular}{lll}
\hline \multicolumn{1}{c}{ Authors } & \multicolumn{1}{c}{ Objectives } \\
\hline Ulysse [96]. & $\begin{array}{l}\text { To study the deviatoric stress tensor } \\
\text { and temperature. } \\
\text { To investigate the influence of the heat source in the } \\
\text { workpiece temperature. }\end{array}$ & $\begin{array}{l}\text { It was found that the pin geometry and the forces act on the tool have a direct effect on } \\
\text { the welding temperatures. } \\
\text { It was investigated that the effect of the pin in the strain rate, stresses and forces in the } \\
\text { heat generation is not too much and the welding heat is mostly generated by } \\
\text { the shoulder. }\end{array}$ \\
\hline Bastier et al. [12]. & To simulate the flow of the material. & It was found that the Eulerian method is a suitable method to simulate the material flow. \\
\hline Bendzsak et al. [98,99]. & To investigate the material flow. & $\begin{array}{l}\text { The behavior of material was investigated, but the results of the temperature were not } \\
\text { found realistic, however, the flow of the material was modelled successfully. }\end{array}$ \\
\hline Contuzzi et al. [102]. & $\begin{array}{l}\text { To investigate the thermal contact conductance } \\
\text { during the FSW. }\end{array}$ & $\begin{array}{l}\text { IT was observed that the clamping system has no influence on the temperature. } \\
\text { There is a "V" shape pattern across the welding cross section. }\end{array}$ \\
\hline Cho et al. [103]. & $\begin{array}{l}\text { To investigate thermomechanical behavior of } \\
\text { the process. }\end{array}$ & $\begin{array}{l}\text { Modelling of the strain hardening and texture evolution was done successfully. The } \\
\text { temperatures pattern at the upper part of the tool remains cold, while close to the pin it } \\
\text { rose, and exhibit a comet-like tail at the tool down part. Temperatures at the advancing } \\
\text { side was reported higher. } \\
\text { It was investigated that the void size depends on the welding speeds. } \\
\text { The optimization of the process is designed. }\end{array}$ \\
Zhu et al. [104]. & To produce a defect free weld. &
\end{tabular}




\section{Local Scale}

\section{Arbitrary Lagrangian-Eulerian (ALE)}

The main intention is the modelling of the process inside the Heat Affected Zone (HAZ), when the model is studying at the local level. At this level, the effect of the welding speeds (rotational and transverse speeds), the contact mechanisms, the shape of the pin, the size of the stirring zone and the flow of the material inside the stirring zone can be studied with an acceptable accuracy. Moreover, inside the HAZ, the divergence phenomenon would be appeared, because of the presence of the severe deformation and the large distortions of mesh which both require continuous re-meshing. Therefore, at the local level, the Lagrangian and Eulerian frameworks are not advantageous. ALE approach is found as an appropriate approach for modelling the process at the local level, because in this approach the mesh inside the domains can transfer arbitrarily across the boundaries in order to optimize the elements shapes. To illustrate the point, in this method, the mesh on the domains boundaries and interfaces are able to transfer along with the materials in order to precisely track the boundaries and interfaces of a multi-material system. Moreover, ALE method has one extra degree of freedom in comparison with the Eulerian and Lagrangian formulations. This extra degree of freedom minimizes the problems appeared in the classical kinematical descriptions and combines the respective advantages in the best way. This capability also makes the ALE as suitable method for descripting of the interactions between the interfaces and make it as an appropriate approach for simulating large plastic deformation problems.

ALE formulation was used to model the transient phases by Fourment [105] to solve problems appeared due to the process severe plastic deformation. A finite element volume code has been employed by Askari et al. [106] as an advection-diffusion solution for the energy balance equation. The elastic response has been considered and the temperature distribution, the strain and the strain rate predicted successfully. Moreover, in the model particle tracking was employed to visualize the flow of the material close to the tool. The mixing fraction was used to investigate the ratio of the flow of the material from the welding advancing side to the retreating side. However, in their research a simplified model for the friction behavior was considered in which the friction coefficient was assumed constant. The results indicated that the movement of the material starts from the welding advancing side, and the material flow in the retreating side is less in comparison to the advancing side.

In a FE model done by Nandan et al. $[107,108]$, a control volume method was used to discretize the FSW process. Temperature, cooling rate and plastic flow were predicted successfully by solving mass conservation, momentum and energy equations. In the model, a non-Newtonian viscosity was used for computing torque amount and strain rate. Finally, total torque and temperature were compared with experimental measurements and finally a good correlation was found.

A model based on the friction was established by Assidi [109]. In the model, the Eulerian and the ALE formulation were used, however for simplicity of the model, the coefficient of the friction was assumed to be constant.

$\mathrm{Xu}$ and Deng [110] used ABAQUS ${ }^{\circledR}$ for modelling the material flow and the distributions of the equivalent plastic strain. In the model ALE method, temperature dependent material properties, adaptive meshing technique and large elasto-plastic deformations were employed to develop the finite element modelling of the process. However, the model was not considered as a fully coupled thermomechanical model, thus, the temperature as an input parameter was defined to the model. It should be noted that, the mentioned temperature was obtained from experimental data. Moreover, the gradient of the velocity at the pin side area was documented. It was investigated that, at the welding advancing side, the temperature and the velocity are higher in comparison with the welding retreating side. Finally, the numerical results and the experimental measurements were compared and an acceptable correlation was achieved in terms of the distributions of the equivalent plastic strain and the microstructure zones distribution. 
Temperature, strain rate, strain and micro-hardness in different welding conditions were established by Heurtier et al. [111] using heat input parameters and the velocity field for AA 2024-T351 in a three dimensional semi-analytical coupled thermo-mechanical model.

Schmidt and Hattel [112] used a 3D fully coupled thermomechanical finite element model. In their model, the ALE method and Johnson-Cook material model were employed in ABAQUS/Explicit ${ }^{\circledR}$. The flexibility of the friction stir welding machine was used as a cylindrical volume model for simplifying the connection of the rigid body (tool) to the work-piece (inlet and outlet boundary conditions).

Based on error estimation, the ALE method and an adaptive re-meshing structure as a splitting approach [113] was employed for predicting the distribution of the temperature using a constant friction coefficient value.

By only considering the thermal actions in a FEM, the residual stress and the temperature was predicted for simulating of the FSW for butt joints using a single block method [114].

By using the ALE approach, the geometry of the tool was established by Santiago et al. [115]. A simple friction model in the slipping/sticking conditions at the interfaces of the pin shoulder/ workpiece area were calculated in the model.

By using a sub-grid scale stabilized mixed velocity, both the pressure and the temperature in different coupled thermo-rigid-plastic models, the thermal modelling of the FSW process was investigated by Agelet de Saracibar et al. [106] Chiumenti et al. [116], and Dialami et al. [117-119]. In all models, the Eulerian and the Arbitrary Lagrangian Eulerian (ALE) approaches were employed. Chiumenti et al. [116,120] and Dialami et al. [62,117,121], also employed an appropriate kinematic framework for simulating the process. Moreover, a comparison between the solid method with other methods has been done in all models. The Lagrangian, the Eulerian and the ALE approaches were proposed as an efficient coupling strategy at different welding zones. Furthermore, in the models, the kinematic setting allowed efficient treatment of arbitrary pin geometries and facilitated the boundary conditions application. Meyghani et al. [122] proposed a mathematical formulation for calculating the friction coefficient as a function of temperature. In the research, thermal analysis of the FSW during various welding parameters were done and the results compared with experiments. Table 4 shows a summary of those researchers that used the ALE formulations.

Table 4. Summary and the outlook of the research which was used ALE (arbitrary LagrangianEulerian) methods.

\begin{tabular}{lll}
\hline \multicolumn{1}{c}{ Authors } & \multicolumn{1}{c}{ Objectives } & \multicolumn{1}{c}{ Results } \\
\hline Fourment [105] & $\begin{array}{l}\text { To avoid large plastic } \\
\text { deformation. }\end{array}$ & $\begin{array}{l}\text { Lagrangian and ALE formulations were compared. ALE } \\
\text { method was found suitable for analyzing the weld seam } \\
\text { and for the whole structure Lagrangian found as a } \\
\text { suitable method. }\end{array}$ \\
\hline Askari et al. [106] & $\begin{array}{l}\text { To compute strain and } \\
\text { temperature variations } \\
\text { during the FSW. }\end{array}$ & $\begin{array}{l}\text { An advection-diffusion solution for solving the equation } \\
\text { of the energy balance was used. } \\
\text { The material flow, strain, strain rate and the distribution } \\
\text { of the temperature were predicted successfully. The } \\
\text { results indicated that the temperature and the material } \\
\text { flow at the welding advancing side was higher than the } \\
\text { retreating side. }\end{array}$ \\
\hline Nandan et al. [107,108] & $\begin{array}{l}\text { Temperature, cooling rate and plastic flow were predicted } \\
\text { successfully. ALE was found as an appropriate approach } \\
\text { for simulating the weld seam. }\end{array}$ \\
\hline Assidi [109] & $\begin{array}{l}\text { The model based on the tool and the friction coefficient } \\
\text { flow and the heat transfers constant. However, the results of the } \\
\text { temperature were unrealistic. }\end{array}$ \\
\hline
\end{tabular}


Table 4. Cont.

\begin{tabular}{|c|c|c|}
\hline Authors & Objectives & Results \\
\hline $\mathrm{Xu}$ and Deng [110] & $\begin{array}{l}\text { To model the temperature } \\
\text { and the flow of the material. }\end{array}$ & $\begin{array}{l}\text { As an input parameter, the temperature was gained from } \\
\text { experiments. The material velocity was reported higher in } \\
\text { the advancing side. }\end{array}$ \\
\hline Heurtier et al. [110] & $\begin{array}{l}\text { To compare temperature, } \\
\text { strain rate, strain and } \\
\text { micro-hardness during } \\
\text { various welding } \\
\text { parameters. }\end{array}$ & $\begin{array}{l}\text { Thermomechanical simulation of the process was done } \\
\text { successfully and the influence of the process parameters } \\
\text { in the temperature, strain rate, strain and micro-hardness } \\
\text { was discussed in detail. ALE method was also used for } \\
\text { the weld seam in all specimens. }\end{array}$ \\
\hline Schmidt and Hattel [112] & $\begin{array}{l}\text { To investigate } \\
\text { thermomechanical behavior } \\
\text { of FSW. }\end{array}$ & $\begin{array}{l}\text { By using ALE method, the friction behavior at the } \\
\text { tool/surface interface and thermomechanical behavior of } \\
\text { FSW were analyzed. }\end{array}$ \\
\hline Assidi et al. [113] & $\begin{array}{l}\text { To model the friction } \\
\text { behavior of FSW. }\end{array}$ & $\begin{array}{l}\text { The effect of the friction coefficient and different friction } \\
\text { models in the temperature during the welding were } \\
\text { discussed in detail. }\end{array}$ \\
\hline Buffa et al. [114] & $\begin{array}{l}\text { To predict temperature and } \\
\text { residual stresses. }\end{array}$ & $\begin{array}{l}\text { The residual stress and temperature were predicted } \\
\text { successfully and ALE approach was found as an } \\
\text { appropriate approach for simulating the weld seam. }\end{array}$ \\
\hline Santiago et al. [115] & $\begin{array}{l}\text { To investigate } \\
\text { thermomechanical behavior } \\
\text { of the process. }\end{array}$ & $\begin{array}{l}\text { Friction model in the slipping/sticking conditions } \\
\text { considered in order to thermomechanical modelling of } \\
\text { FSW. The results showed a good agreement with } \\
\text { the reality. }\end{array}$ \\
\hline $\begin{array}{l}\text { Agelet de Saracibar et al. [106], } \\
\text { Chiumenti et al. [116], and } \\
\text { Dialami et al. [117-119] }\end{array}$ & $\begin{array}{l}\text { To model the plastic } \\
\text { deformation and } \\
\text { thermal analysis. }\end{array}$ & $\begin{array}{l}\text { Numerical modeling of the process and kinematic } \\
\text { frameworks were discussed in detail and different FEMs } \\
\text { were compared. A good correlations was found with } \\
\text { the reality. }\end{array}$ \\
\hline $\begin{array}{l}\text { Chiumenti et al. }[116,120] \text { and } \\
\text { Dialami et al. }[62,117,121]\end{array}$ & $\begin{array}{l}\text { To compare the solid } \\
\text { method with other methods } \\
\text { for thermal analysis of } \\
\text { the process. }\end{array}$ & $\begin{array}{l}\text { Thermal analysis of FSW process was done successfully. } \\
\text { Different welding methods including ALE, Eulerian and } \\
\text { Lagrangian methods were compared and analyzed. }\end{array}$ \\
\hline Meyghani et al. [122] & To thermal analysis of FSW. & $\begin{array}{l}\text { A proper calculation of the friction coefficient increases } \\
\text { the accuracy of the FSW thermal simulation. }\end{array}$ \\
\hline
\end{tabular}

In conclusion, the ALE approach was found as an appropriate method for modelling of continuum mechanics problems in which severe plastic deformation or high material shearing are present (like the metal forming processes). In a comparison between the Eulerian and the Lagrangian approaches, when large plastic deformation is present in the model, the application of ALE is higher due to the easily movement of boundaries and the large changes in the volume of the computational domain.

\section{Discussion}

Figure 4 indicates a graphical evidence for a number of researchers who have employed different numerical approaches. Moreover, comparisons between different approaches are summarized as the following:

- At the global scale simulation, the Lagrangian method is found as a suitable method to model the process, because in the Lagrangian method the position of the material points relative to the nodes remained fixed.

- The Eulerian approach was found as an appropriate method for modelling the material flow and the fluid flows, because in this method nodes remain fixed and the material points can move inside the mesh.

- ALE was found as an appropriate approach for analyzing the processes inside the stirring zone (local level), because in this method the mesh is able to refine gradually throughout the welding seam. 


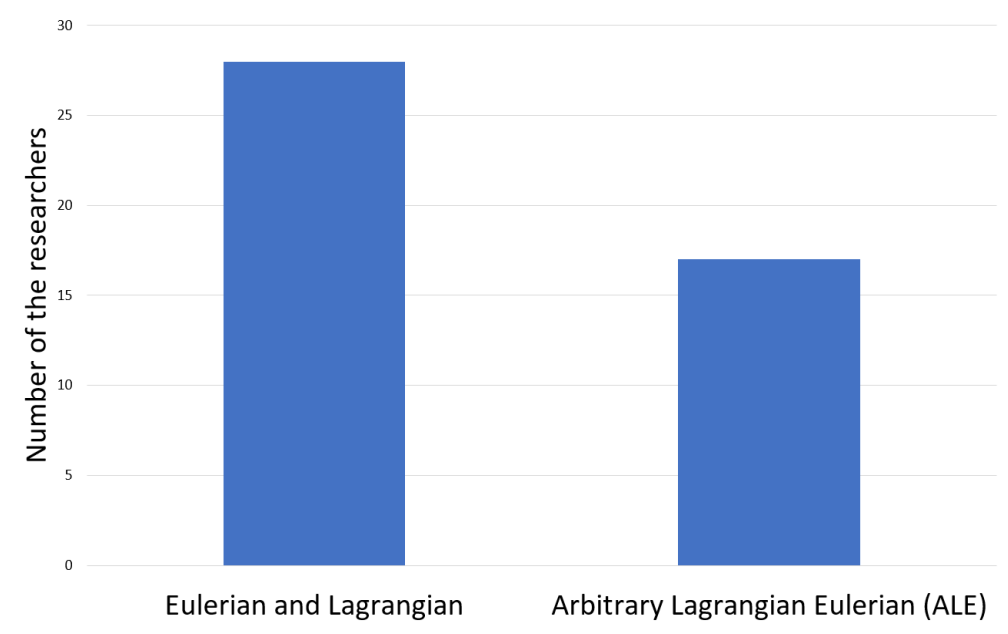

Figure 4. Number of researchers who employed different approaches.

\subsection{Conclusions from the Thermal Analysis Were Obtained as Follows}

- It was reported that at higher temperatures, between the lower and the upper surfaces of the workpiece, there is a small gap inside the stirring zone. This gap becomes smaller as the distance from the welding center rises.

- The generated heat by the tool shoulder is more in comparison with the heat that is produced by the tool pin.

- The temperature pattern at the shoulder bottom surface had an asymmetrical shape and the temperate at the welding retreating side was reported lower in comparison to the advancing side.

- The variations of the temperature inside the stirring zone were usually reported as a quasi-steady phenomenon, but as the distance from the welding seam rises, the quasi-steady phenomenon faded.

- By increasing the transverse velocity, a reduction in the welding temperature has been observed.

- Unlike the transverse velocity, the welding temperature gradually rises at higher rotational speeds.

\subsection{From the Literature Survey, a Number of Gaps in the Knowledge was Obtained as Follows}

- Numerical modelling of High-Speed Friction Stir welding has not yet been fully understood by researchers, because as the welding speed increases the divergence problem will also increase in the model.

- In order to decrease the costs of the experimental test, the lack of a mathematical model in which the material property can be calculated is necessary, because in the literature the material property is usually gained form the experimental data which always costs a lot.

- A proper calculation of the surface interaction including temperature dependent friction coefficient values have not yet fully understood, while the friction coefficient is one of the most significant parameters in the process simulation.

- Joining of similar and dissimilar aluminum alloys has not yet fully understood numerically, thus it remains one of the significant objectives that would be interested by many researchers.

- Numerical simulation of the different thicknesses can attract enormous research interest.

- Evidence indicated that most of the literature is concentrated on the homogeneous materials and there is lack of knowledge in the numerical simulation of the metal matrix composites (MMC).

- All of the literature is focused on a linear friction stir welding, while in reality the welding seam might be nonlinear or curvature, therefore a lack in the modelling of the curvature friction stir welding need to be investigated. 


\section{Conclusions}

Experimental study of the thermal behavior during FSW process have been widely studied. However, in experimental observations the costs and time needed, are relatively high, therefore in order to reduce costs and times, the numerical modelling approach of the FSW process is now very common between researchers and it is reflected by the number of published literature covering this topic. In this study, different modelling methods for thermal modelling of the FSW were reviewed. Three different simulation methods (Lagrangian, Eulerian and Arbitrary Lagrangian-Eulerian (ALE)) for simulating the process were identified and compared. It was summarized that, the numerical analysis of the process can be studied at the global level (considering the whole structure), or can be studied locally (exploring the process further in detail or inside the Heat Affected Zone). The survey indicated that, the Lagrangian method is suitable for modelling the structural component (global level). In the local level, a combination of the Lagrangian and the Eulerian approaches called ALE was identified as an appropriate approach. There are some potentials for the future work, such as using an accurate material data (temperature dependent). Moreover, numerical simulation of different thicknesses can attract the attention of some researchers. Furthermore, joining of the dissimilar materials is usually more difficult in comparison with joining similar material or those materials that have minor differences. Therefore, numerical investigation of joining of dissimilar materials can attract immense research interests. Besides, evidence shows that there is an absence in the simulation of metal matrix composites (MMC), because most of the literature is focused on the homogeneous metals and alloys. Thus, further study is required for thermomechanical or thermal analysis of FSW of MMC. In addition, the modelling of the curvature welding seam seems to be as an attractive research topic for the future study.

Acknowledgments: The authors would like to acknowledge the financial support from Universiti Teknologi PETRONAS (UTP), Bandar Seri Iskandar, Perak Darul Ridzuan, Malaysia and the financial support from the Ministry of Higher Education (MOHE) Malaysia through Fundamental Research Grant Scheme (FRGS) grant No. FRGS/1/2015/TK03/UTP/02/6.

Author Contributions: Bahman Meyghani created the initial conception and work plan as well as the overall and final drafting and revising of the manuscript; Mokhtar B. Awang supervised the development of the work, helped in data interpretation, and manuscript evaluation; Seyed Sattar Emamian assisted in conceptualizing the work and its realization; Mohd Khalid B. Mohd Nor helped evaluate and edit the manuscript and Srinivasa Rao Pedapati suggested revisions for the final manuscript.

Conflicts of Interest: The authors declare no conflict of interest.

\section{References}

1. Hicks, J. Welded Design-Theory and Practice; Abington Publishing: Cambridge, UK, 2000.

2. Sharma, H.K.; Bhatt, K.; Shah, K.; Joshi, U. Experimental analysis of friction stir welding of dissimilar alloys AA6061 and Mg AZ31 using circular butt joint geometry. Procedia Technol. 2016, 23, 566-572. [CrossRef]

3. Tufaro, L.N.; Manzoni, I.; Svoboda, H.G. Effect of heat input on AA5052 friction stir welds characteristics. Procedia Mater. Sci. 2015, 8, 914-923. [CrossRef]

4. Tozaki, Y.; Uematsu, Y.; Tokaji, K. A newly developed tool without probe for friction stir spot welding and its performance. J. Mater. Process. Technol. 2010, 210, 844-851. [CrossRef]

5. Kumar, K.N.; Raju, P.R. Dissimilar materials of friction stir welding-Overview. IJETT 2017, 44. [CrossRef]

6. Emamian, S.; Awang, M.; Hussai, P.; Meyghani, B.; Zafar, A. Influences of tool pin profile on the friction stir welding of AA6061. ARPN Eng. Appl. Sci. 2006, 11, 12258-12261.

7. He, X.; Gu, F.; Ball, A. Recent development in finite element analysis of self-piercing riveted joints. Int. J. Adv. Manuf. Technol. 2012, 58, 643-649. [CrossRef]

8. He, X. Finite element analysis of laser welding: A state of art review. Mater. Manuf. Process. 2012, 27, 1354-1365. [CrossRef]

9. He, X. A review of finite element analysis of adhesively bonded joints. Int. J. Adhes. Adhes. 2011, 31, $248-264$. [CrossRef] 
10. He, X. Recent development in finite element analysis of clinched joints. Int. J. Adv. Manuf. Technol. 2010, 48, 607-612. [CrossRef]

11. He, X.; Pearson, I.; Young, K. Self-pierce riveting for sheet materials: State of the art. J. Mater. Process. Technol. 2008, 199, 27-36. [CrossRef]

12. Thomas, W. Friction Stir Butt Welding. International Patent Application No. PCT/GB92/0220, 6 December 1991.

13. Silva, A.C.; Braga, D.F.; de Figueiredo, M.; Moreira, P. Ultimate tensile strength optimization of different FSW aluminium alloy joints. Int. J. Adv. Manuf. Technol. 2015, 79, 805-814. [CrossRef]

14. Sonne, M.R.; Tutum, C.C.; Hattel, J.H.; Simar, A.; De Meester, B. The effect of hardening laws and thermal softening on modeling residual stresses in FSW of aluminum alloy 2024-T3. J. Mater. Process. Technol. 2013, 213, 477-486. [CrossRef]

15. Cao, X.; Jahazi, M. Effect of tool rotational speed and probe length on lap joint quality of a friction stir welded magnesium alloy. Mater. Des. 2011, 32,1-11. [CrossRef]

16. Chowdhury, S.; Chen, D.; Bhole, S.; Cao, X. Tensile properties of a friction stir welded magnesium alloy: Effect of pin tool thread orientation and weld pitch. Mater. Sci. Eng. A 2010, 527, 6064-6075. [CrossRef]

17. Kitamura, K.; Fujii, H.; Iwata, Y.; Sun, Y.; Morisada, Y. Flexible control of the microstructure and mechanical properties of friction stir welded Ti-6Al-4V joints. Mater. Des. 2013, 46, 348-354. [CrossRef]

18. Buffa, G.; Fratini, L.; Micari, F. Mechanical and microstructural properties prediction by artificial neural networks in FSW processes of dual phase titanium alloys. J. Manuf. Process. 2012, 14, 289-296. [CrossRef]

19. Sharifitabar, M.; Nami, H. Microstructures of dissimilar friction stir welded joints between 2024-T4 aluminum alloy and $\mathrm{Al} / \mathrm{Mg}_{2} \mathrm{Si}$ metal matrix cast composite. Compos. Part B Eng. 2011, 42, 2004-2012. [CrossRef]

20. Bozkurt, Y.; Uzun, H.; Salman, S. Microstructure and mechanical properties of friction stir welded particulate reinforced AA2124/SiC/25p-T4 composite. J. Compos. Mater. 2011, 45, 2237-2245. [CrossRef]

21. Sorensen, C.D.; Nelson, T.W. Friction Stir Welding of Ferrous and Nickel Alloys. In Friction Stir Welding and Processing; ASM International: Materials Park, OH, USA, 2007; pp. 111-121.

22. Hasan, A.; Bennett, C.; Shipway, P.; Cater, S.; Martin, J. A numerical methodology for predicting tool wear in friction stir welding. J. Mater. Process. Technol. 2017, 241, 129-140. [CrossRef]

23. Kim, J.R.; Ahn, E.Y.; Das, H.; Jeong, Y.H.; Hong, S.T.; Miles, M.; Lee, K.J. Effect of tool geometry and process parameters on mechanical properties of friction stir spot welded dissimilar aluminum alloys. Int. J. Precis. Eng. Manuf. 2017, 18, 445-452. [CrossRef]

24. Sahlot, P.; Jha, K.; Dey, G.; Arora, A. Quantitative wear analysis of H13 steel tool during friction stir welding of $\mathrm{Cu}-0.8 \% \mathrm{Cr}-0.1 \% \mathrm{Zr}$ alloy. Wear 2017, 378, 82-89. [CrossRef]

25. Zhong, Y.; Wu, C.; Padhy, G. Effect of ultrasonic vibration on welding load, temperature and material flow in friction stir welding. J. Mater. Process. Technol. 2017, 239, 273-283. [CrossRef]

26. Nguyen, N.; Kim, D.; Kim, H. Assessment of the failure load for an AA6061-T6 friction stir spot welding joint. J. Eng. Manuf. 2011, 225, 1746-1756. [CrossRef]

27. Miličić, M.; Gladović, P.; Bojanić, R.; Savković, T.; Stojić, N. Friction stir welding (FSW) process of copper alloys. Metalurgija 2016, 55, 107-110.

28. Kutum, P.; Borah, M.J. Experimental Analysis on Friction Stir Welding Process Parameters on Temperature Distribution. In Trends in Industrial and Mechanical Engineering; Verma, A., Soni, V.K., Soni, P.K., Eds.; Maulana Azad National Institute of Technology: Bhopal, India, 2016; p. 91.

29. Silva, E.P.D.; Oliveira, V.B.; Pereira, V.F.; Maluf, O.; Buzolin, R.H.; Pinto, H.C. Microstructure and residual stresses in a friction stir welded butt joint of as-cast ZK60 alloy containing rare earths. Mater. Res. 2017, 20. [CrossRef]

30. Dixit, S.; Madhu, H.; Kailas, S.; Chattopadhyay, K. Role of insert material on process loads during FSW. Int. J. Adv. Manuf. Technol. 2017, 91, 3427-3435. [CrossRef]

31. Elangovan, K. Communication to the editor: Friction stir welding (FSW)-accelerating automobile industries. Int. J. Des. Manuf. Technol. 2016, 10, 2. [CrossRef]

32. Schmidt, H.B.; Hattel, J.H. Thermal modelling of friction stir welding. Scr. Mater. 2008, 58, 332-337. [CrossRef]

33. Banjare, P.N.; Sahlot, P.; Arora, A. An assisted heating tool design for FSW of thermoplastics. J. Mater. Process. Technol. 2017, 239, 83-91. [CrossRef] 
34. Reynolds, A. Efficacy of the Stationary Shoulder Tool for Modifying the Heat Input during Friction Stir Welding. In Proceedings of the 28th Advanced Aerospace Materials and Processes (AeroMat) Conference and Exposition, Charleston, CA, USA, 10-12 April 2017; ASM International: Materials Park, OH, 2017.

35. Widener, C.; Talia, J.; Tweedy, B.; Burford, D. High-Rotational Speed Friction Stir Welding with a Fixed Shoulder. In Proceedings of the 6th International Symposium on Friction Stir Welding, Montreal, QC, Canada, 10-13 October 2006; National Institute for Aviation Research, Wichita State University: Wichita, KS, USA, 2006.

36. Chen, C.; Kovacevic, R. Finite element modeling of friction stir welding-Thermal and thermomechanical analysis. Int. J. Mach. Tools Manuf. 2003, 43, 1319-1326. [CrossRef]

37. Simar, A.; Lecomte-Beckers, J.; Pardoen, T.; De Meester, B. Effect of boundary conditions and heat source distribution on temperature distribution in friction stir welding. Sci. Technol. Weld. Join. 2006, 11, 170-177. [CrossRef]

38. Zhang, Z. Comparison of two contact models in the simulation of friction stir welding process. J. Mater. Sci. 2008, 43, 5867-5877. [CrossRef]

39. Mitsufuji, K.; Nambu, M.; Miyasaka, F. Numerical Analysis of FSW Employing Discrete Element Method. In Friction Stir Welding and Processing IX; Springer: Berlin, Germany, 2017; pp. 311-319.

40. Bagalkot, N.; Hamouda, A.A. Experimental and numerical method for estimating diffusion coefficient of the carbon dioxide into light components. Ind. Eng. Chem. Res. 2017, 56, 2359-2374. [CrossRef]

41. Mishra, R.S.; Ma, Z. Friction stir welding and processing. Mater. Sci. Eng. R Rep. 2005, 50, 1-78. [CrossRef]

42. Threadgill, P.; Leonard, A.; Shercliff, H.; Withers, P. Friction stir welding of aluminium alloys. Int. Mater. Rev. 2009, 54, 49-93. [CrossRef]

43. Çam, G. Friction stir welded structural materials: Beyond Al-alloys. Int. Mater. Rev. 2011, 56, 1-48. [CrossRef]

44. He, X.; Gu, F.; Ball, A. A review of numerical analysis of friction stir welding. Prog. Mater. Sci. 2014, 65, 1-66. [CrossRef]

45. Serio, L.; Palumbo, D.; Galietti, U.; De Filippis, L.; Ludovico, A. Monitoring of the friction stir welding process by means of thermography. Nondestr. Test. Eval. 2016, 31, 371-383. [CrossRef]

46. Serio, L.M.; Palumbo, D.; De Filippis, L.; Galietti, U.; Ludovico, A. Effect of friction stir process parameters on the mechanical and thermal behavior of 5754-H111 aluminum plates. Materials 2016, 9, 122. [CrossRef] [PubMed]

47. Shah, P.H.; Badheka, V.J. Friction stir welding of aluminium alloys: An overview of experimental findings-Process, variables, development and applications. J. Mater. Des. Appl. 2017. [CrossRef]

48. Davim, J.P. Modern Manufacturing Engineering; Springer: Cham, Switzerland, 2015.

49. Schmidt, H.; Hattel, J. A local model for the thermomechanical conditions in friction stir welding. Model. Simul. Mater. Sci. Eng. 2004, 13, 77. [CrossRef]

50. Kim, D.; Badarinarayan, H.; Kim, J.H.; Kim, C.; Okamoto, K.; Wagoner, R.; Chung, K. Numerical simulation of friction stir butt welding process for AA5083-H18 sheets. Eur. J. Mech. A Solids 2010, 29, 204-215. [CrossRef]

51. Patil, S.; Tay, Y.Y.; Baratzadeh, F.; Lankarani, H. Modeling of friction-stir butt-welds and its application in automotive bumper impact performance Part 2. Impact modeling and bumper crash performance. J. Mech. Sci. Technol. 2017, 31, 3225-3232. [CrossRef]

52. Babu, N.; Karunakaran, N.; Balasubramanian, V. Numerical predictions and experimental investigation of the temperature distribution of friction stir welded AA 5059 aluminium alloy joints. Int. J. Mater. Res. 2017, 108, 68-75. [CrossRef]

53. Meyghani, B.; Awang, M.; Emamian, S. A comparative study of finite element analysis for friction stir welding application. ARPN J. Eng. Appl. Sci. 2006, 11, 12984-12989.

54. Dialami, N.; Cervera, M.; Chiumenti, M.; De Saracibar, C.A. A fast and accurate two-stage strategy to evaluate the effect of the pin tool profile on metal flow, torque and forces in friction stir welding. Int. J. Mech. Sci. 2017, 122, 215-227. [CrossRef]

55. Peel, M.; Steuwer, A.; Preuss, M.; Withers, P.J. Microstructure, mechanical properties and residual stresses as a function of welding speed in aluminium AA5083 friction stir welds. Acta Mater. 2003, 51, 4791-4801. [CrossRef]

56. Mishra, R.S. Friction stir processing technologies. Adv. Mater. Process. 2003, 161, 43-46.

57. Nandan, R.; DebRoy, T.; Bhadeshia, H. Recent advances in friction-stir welding-process, weldment structure and properties. Prog. Mater. Sci. 2008, 53, 980-1023. [CrossRef] 
58. Guerdoux, S.; Fourment, L. A 3D numerical simulation of different phases of friction stir welding. Model. Simul. Mater. Sci. Eng. 2009, 17, 075001. [CrossRef]

59. Veljić, D.M.; Rakin, M.P.; Perović, M.M.; Međo, B.I.; Radaković, Z.J.; Todorović, P.M.; Pavišić, M.N. Heat generation during plunge stage in friction stir welding. Therm. Sci. 2013, 17, 489-496. [CrossRef]

60. Sun, T.; Roy, M.; Strong, D.; Withers, P.J.; Prangnell, P.B. Comparison of residual stress distributions in conventional and stationary shoulder high-strength aluminum alloy friction stir welds. J. Mater. Process. Technol. 2017, 242, 92-100. [CrossRef]

61. Garg, A.; Bhattacharya, A. On lap shear strength of friction stir spot welded AA6061 alloy. J. Manuf. Process. 2017, 26, 203-215. [CrossRef]

62. Bussetta, P.; Dialami, N.; Boman, R.; Chiumenti, M.; Agelet de Saracibar, C.; Cervera, M.; Ponthot, J.P. Comparison of a fluid and a solid approach for the numerical simulation of friction stir welding with a non-cylindrical pin. Steel Res. Int. 2014, 85, 968-979. [CrossRef]

63. Jain, R.; Pal, S.K.; Singh, S.B. Finite element simulation of temperature and strain distribution during friction stir welding of AA2024 aluminum alloy. J. Inst. Eng. Ser. C 2017, 98, 37-43. [CrossRef]

64. Riahi, M.; Nazari, H. Analysis of transient temperature and residual thermal stresses in friction stir welding of aluminum alloy 6061-T6 via numerical simulation. Int. J. Adv. Manuf. Technol. 2011, 55, 143-152. [CrossRef]

65. Aziz, S.B.; Dewan, M.W.; Huggett, D.J.; Wahab, M.A.; Okeil, A.M.; Liao, T.W. Impact of friction stir welding (FSW) process parameters on thermal modeling and heat generation of aluminum alloy joints. Acta Metall. Sin. 2016, 29, 869-883. [CrossRef]

66. Maisonnette, D.; Bardel, D.; Robin, V.; Nelias, D.; Suery, M. Mechanical behaviour at high temperature as induced during welding of a 6xxx series aluminium alloy. Int. J. Press. Vessel. Pip. 2017, 149, 55-65. [CrossRef]

67. Al-Badour, F.; Merah, N.; Shuaib, A.; Bazoune, A. Coupled Eulerian Lagrangian finite element modeling of friction stir welding processes. J. Mater. Process. Technol. 2013, 213, 1433-1439. [CrossRef]

68. Janjić, M.; Vukčević, M.; Mandić, V.; Pavletić, D.; Šibalić, N. Microstructural evolution during friction stir welding of AlSi1MgMn alloy. Metalurgija 2012, 51, 29-33.

69. Guerra, M.; Schmidt, C.; McClure, J.; Murr, L.; Nunes, A. Flow patterns during friction stir welding. Mater. Charact. 2002, 49, 95-101. [CrossRef]

70. Lee, W.; Yeon, Y.; Jung, S. Joint properties of friction stir welded AZ31B-H24 magnesium alloy. Mater. Sci. Technol. 2003, 19, 785-790. [CrossRef]

71. Su, J.Q.; Nelson, T.; Mishra, R.; Mahoney, M. Microstructural investigation of friction stir welded 7050-T651 aluminium. Acta Mater. 2003, 51, 713-729. [CrossRef]

72. Mukherjee, A.; Patel, N.V.; Gurjar, K.C. Review paper on friction stir welding and its impact on environment. IRJET 2017, 4, 1481-1490.

73. Fourment, L.; Gastebois, S.; Dubourg, L.; Chinesta, F.; Cueto, E.; Abisset-Chavanne, E. Calibration of 3D ALE Finite Element Model from Experiments on Friction Stir Welding of Lap Joints. In Proceedings of the 19th International ESAFORM Conference on Material Forming, Nantes, France, 27-29 April 2016; AIP Publishing: Melville, NY, USA, 2016.

74. Cremonesi, M.; Meduri, S.; Perego, U.; Frangi, A. An explicit Lagrangian finite element method for free-surface weakly compressible flows. Comput. Part. Mech. 2017, 4, 359-369. [CrossRef]

75. Boscheri, W.; Dumbser, M. High order accurate direct Arbitrary-Lagrangian-Eulerian ADER-WENO finite volume schemes on moving curvilinear unstructured meshes. Comput. Fluids 2016, 136, 48-66. [CrossRef]

76. Barlow, A.J.; Maire, P.H.; Rider, W.J.; Rieben, R.N.; Shashkov, M.J. Arbitrary Lagrangian-Eulerian methods for modeling high-speed compressible multimaterial flows. J. Comput. Phys. 2016, 322, 603-665. [CrossRef]

77. Fu, L.; Duan, L.; Du, S. Numerical simulation of inertia friction welding process by finite element method. Weld. J. 2003, 82, 65-70.

78. Ghanimi, Y.; Cerjak, H.; Faes, K. Modelling of Friction Welding of Long Components. In Trends in Welding Research: Proceedings of the 6th International Conference, Callaway Gardens Resort, Phoenix, Arizona, 15-19 April 2002; David, S.A., Ed.; ASM International: Geauga County, OH, USA, 2002.

79. Gould, J.E.; Feng, Z. Heat flow model for friction stir welding of aluminum alloys. J. Mater. Process. Manuf. Sci. 1998, 7, 185-194. [CrossRef]

80. Chenot, J.L.; Massoni, E. Finite element modelling and control of new metal forming processes. Int. J. Mach. Tools Manuf. 2006, 46, 1194-1200. [CrossRef] 
81. Buffa, G.; Hua, J.; Shivpuri, R.; Fratini, L. A continuum based fem model for friction stir welding-Model development. Mater. Sci. Eng. A 2006, 419, 389-396. [CrossRef]

82. Buffa, G.; Hua, J.; Shivpuri, R.; Fratini, L. Design of the friction stir welding tool using the continuum based FEM model. Mater. Sci. Eng. A 2006, 419, 381-388. [CrossRef]

83. Dialami, N.; Chiumenti, M.; Cervera, M.; de Saracibar, C.A. Challenges in thermo-mechanical analysis of friction stir welding processes. Arch. Comput. Methods Eng. 2017, 24, 189-225. [CrossRef]

84. Dong, P.; Lu, F.; Hong, J.; Cao, Z. Coupled thermomechanical analysis of friction stir welding process using simplified models. Sci. Technol. Weld. Join. 2013, 6, 281-287. [CrossRef]

85. Chao, Y.J.; Qi, X.; Tang, W. Heat transfer in friction stir welding-Experimental and numerical studies. J. Manuf. Sci. Eng. 2003, 125, 138-145. [CrossRef]

86. Song, M.; Kovacevic, R. A New Heat Transfer Model for Friction Stir Welding; Society of Manufacturing Engineers: Dearborn, MI, USA, 2002.

87. Song, M.; Kovacevic, R.; Ouyang, J.; Valant, M. A Detailed Three-Dimensional Transient Heat Transfer Model for Friction Stir Welding. In Trends in Welding Research: Proceedings of the 6th International Conference, Callaway Gardens Resort, Phoenix, Arizona, 15-19 April 2002; David, S.A., Ed.; ASM International: Geauga County, OH, USA, 2002.

88. Dialami, N.; Chiumenti, M.; Cervera, M.; de Saracibar, C.A. Local and Global Approaches to Friction Stir Welding; International Center for Numerical Methods in Engineering: Barcelona, Spain, 2016.

89. Song, M.; Kovacevic, R. Numerical and experimental study of the heat transfer process in friction stir welding. J. Eng. Manuf. 2003, 217, 73-85. [CrossRef]

90. Chao, Y.J.; Qi, X. Thermal and thermo-mechanical modeling of friction stir welding of aluminum alloy 6061-T6. J. Mater. Process. Manuf. Sci. 1998, 7, 215-233. [CrossRef]

91. Colegrove, P. Three Dimensional OW and Thermal Modelling of Thermomechanical Performance of Friction Stir Welding. In Proceedings of the 2nd International Symposium on Friction Stir Welding, Gothenburg, Sweden, 27-28 June 2000.

92. Khandkar, M.; Khan, J.A.; Reynolds, A.P. Prediction of temperature distribution and thermal history during friction stir welding: Input torque based model. Sci. Technol. Weld. Join. 2013, 8, 165-174. [CrossRef]

93. Hamilton, C.; Dymek, S.; Sommers, A. A thermal model of friction stir welding in aluminum alloys. Int. J. Mach. Tools Manuf. 2008, 48, 1120-1130. [CrossRef]

94. Khandkar, M.Z.H.; Khan, J.A.; Reynolds, A.P.; Sutton, M.A. Predicting residual thermal stresses in friction stir welded metals. J. Mater. Process. Technol. 2006, 174, 195-203. [CrossRef]

95. Dong, P.; Lu, F.; Hong, J.; Cao, Z. Analysis of Weld Formation Process in Friction Stir Welding. In Proceedings of the 1st Friction Stir Welding Symposium, Thousand Oaks, CA, USA, 14-16 June 1999.

96. Ulysse, P. Three-dimensional modeling of the friction stir-welding process. Int. J. Mach. Tools Manuf. 2002, 42, 1549-1557. [CrossRef]

97. Chen, C.; Kovacevic, R. Thermomechanical modelling and force analysis of friction stir welding by the finite element method. J. Mech. Eng. Sci. 2004, 218, 509-519. [CrossRef]

98. Bendzsak, G.; North, T.; Smith, C. An Experimentally Validated 3D Model for Friction Stir Welding. In Proceedings of the Second International Symposium on Friction Stir Welding, Gothenburg, Sweden, 27-29 June 2000.

99. North, T.; Bendzsak, G.; Smith, C. Material Properties Relevant to 3-D FSW Modeling. In Proceedings of the Second International Symposium on Friction Stir Welding, Gothenburg, Sweden, 27-29 June 2000.

100. Bastier, A.; Maitournam, M.; Dang Van, K.; Roger, F. Steady state thermomechanical modelling of friction stir welding. Sci. Technol. Weld. Join. 2006, 11, 278-288. [CrossRef]

101. Braeunig, J.P.; Chaudet, B. Study of a collocated Lagrange-remap scheme for multi-material flows adapted to HPC. Int. J. Numer. Methods Fluids 2017, 83, 664-678. [CrossRef]

102. Contuzzi, N.; Campanelli, S.; Casalino, G.; Ludovico, A. On the role of the Thermal Contact Conductance during the Friction Stir Welding of an AA5754-H111 butt joint. Appl. Therm. Eng. 2016, 104, 263-273. [CrossRef]

103. Cho, J.H.; Boyce, D.E.; Dawson, P.R. Modeling strain hardening and texture evolution in friction stir welding of stainless steel. Mater. Sci. Eng. A 2005, 398, 146-163. [CrossRef]

104. Zhu, Z.; Wang, M.; Zhang, H.; Zhang, X.; Yu, T.; Wu, Z. A finite element model to simulate defect formation during friction stir welding. Metals 2017, 7, 256. [CrossRef] 
105. Guerdoux, S.; Fourment, L.; Miles, M.; Sorensen, C. Numerical Simulation of the Friction Stir Welding Process Using both Lagrangian and Arbitrary Lagrangian Eulerian Formulations. In Materials Processing and Design: Modeling, Simulation and Applications-NUMIFORM 2004, Proceedings of the 8th International Conference on Numerical Methods in Industrial Forming Processes, Columbus, OH, USA, 13-17 June 2004; AIP Publishing: Geauga County, OH, USA, 2004.

106. De Saracibar, C.A.; Chiumenti, M.; Cervera, M.; Dialami, N.; Seret, A. Computational modeling and sub-grid scale stabilization of incompressibility and convection in the numerical simulation of friction stir welding processes. Arch. Comput. Methods Eng. 2014, 21, 3-37. [CrossRef]

107. Nandan, R.; Roy, G.; Lienert, T.; DebRoy, T. Numerical modelling of 3D plastic flow and heat transfer during friction stir welding of stainless steel. Sci. Technol. Weld. Join. 2013, 11, 526-537. [CrossRef]

108. Nandan, R.; Roy, G.; Lienert, T.; DebRoy, T. Three-dimensional heat and material flow during friction stir welding of mild steel. Acta Mater. 2007, 55, 883-895. [CrossRef]

109. Assidi, M.; Fourment, L. Accurate 3D friction stir welding simulation tool based on friction model calibration. Int. J. Mater. Form. 2009, 2, 327-330. [CrossRef]

110. Deng, X.; Xu, S. Two-dimensional finite element simulation of material flow in the friction stir welding process. J. Manuf. Process. 2004, 6, 125-133. [CrossRef]

111. Heurtier, P.; Jones, M.; Desrayaud, C.; Driver, J.H.; Montheillet, F.; Allehaux, D. Mechanical and thermal modelling of friction stir welding. J. Mater. Process. Technol. 2006, 171, 348-357. [CrossRef]

112. Schmidt, H.N.B.; Hattel, J. Modelling Thermomechanical Conditions at the Tool/Matrix Interface in Friction Stir Welding. In Proceedings of the 5th International Friction Stir Welding Symposium, Metz, France, 14-16 September 2004.

113. Assidi, M.; Fourment, L.; Guerdoux, S.; Nelson, T. Friction model for friction stir welding process simulation: Calibrations from welding experiments. Int. J. Mach. Tools Manuf. 2010, 50, 143-155. [CrossRef]

114. Buffa, G.; Ducato, A.; Fratini, L. Numerical procedure for residual stresses prediction in friction stir welding. Finite Elements Anal. Des. 2011, 47, 470-476. [CrossRef]

115. Santiago, D.; Lombera, G.; Urquiza, S.; Agelet de Saracibar Bosch, C.; Chiumenti, M. Modelado termomecánico del proceso de Friction Stir Welding utilizando la geometría real de la herramienta. Rev. Int. Métodos Numér. Cálc. Diseño Ing. 2010, 26, 293-303.

116. Chiumenti, M.; Cervera, M.; de Saracibar, C.A.; Dialami, N. Numerical modeling of friction stir welding processes. Comput. Methods Appl. Mech. Eng. 2013, 254, 353-369. [CrossRef]

117. Dialami, N.; Chiumenti, M.; Cervera, M.; de Saracibar, C.A. An apropos kinematic framework for the numerical modeling of friction stir welding. Comput. Struct. 2013, 117, 48-57. [CrossRef]

118. Dialami, N.; Chiumenti, M.; Cervera, M.; de Saracibar, C.A.; Ponthot, J.P. Material flow visualization in friction stir welding via particle tracing. Int. J. Mater. Form. 2015, 8, 167-181. [CrossRef]

119. Dialami, N.; Chiumenti, M.; Cervera, M.; de Saracibar, C.A.; Ponthot, J.P.; Bussetta, P. Numerical Simulation and Visualization of Material Flow in Friction Stir Welding via Particle Tracing. In Numerical Simulations of Coupled Problems in Engineering; Springer: Berlin, Germany, 2014; pp. 157-169.

120. Chiumenti, M.; Cervera, M.; Agelet de Saracibar, C.; Dialami, N. A Novel Stress-Accurate FE Technology for Highly Non-Linear Analysis with Incompressibility Constraint. Application to the Numerical Simulation of the FSW Process. In Proceedings of the International Conference on Numerical Methods in Forming Processes (NUMIFORM), Shenyang, China, 6-10 July 2013; Volume 1532, pp. 45-56.

121. Bussetta, P.; Dialami, N.; Chiumenti, M.; Agelet de Saracibar, C.; Cervera, M.; Ponthot, J.P. 3D numerical models of FSW processes with non-cylindrical pin. Adv. Mater. Process. Technol. 2015, 1, 275-287. [CrossRef]

122. Meyghani, B.; Awang, M.; Emamian, S.; Khalid, N.M. Developing a Finite Element Model for Thermal Analysis of Friction Stir Welding by Calculating Temperature Dependent Friction Coefficient. In Proceedings of the 2nd International Conference on Mechanical, Manufacturing and Process Plant Engineering, Kuala Lumpur, Malaysia, 23-24 November 2017; Springer: Berlin, Germany, 2017.

(C) 2017 by the authors. Licensee MDPI, Basel, Switzerland. This article is an open access article distributed under the terms and conditions of the Creative Commons Attribution (CC BY) license (http:/ / creativecommons.org/licenses/by/4.0/). 